\title{
Development Aspect of Bengalon Production Forest Management Unit in Kutai Timur Regency
}

\author{
Aliri $^{1, *}$ Mustofa Agung Sardjono ${ }^{2}$ Sigit Hardwinarto ${ }^{2}$ Juremi $^{3}$ \\ Ria Rosdiana Hutagaol ${ }^{4}$
}

\author{
${ }^{1}$ Kutai Timur College of Agriculture, Jl. Soekarno-Hatta Sangatta \\ ${ }^{2}$ Faculty of Forestry, Mulawarman University, Jl. Ki Hajar Dewantara 75116 \\ ${ }^{3}$ Faculty of Agriculture, Mulawarman University, Jl. Pasir Balengkong 756116 \\ ${ }^{4}$ University of Kapuas Sintang, Jl. Y.C Oevang Oeray Sintang \\ *Corresponding author. Email: aryanfaizyal2@gmail.com
}

\begin{abstract}
Kutai Timur Regency has 3 KPHs (Kesatuan Pengelolaan Hutan or Forest Management Unit = FMU), namely KPH Bengalon, KPH Kelinjau, and KPH Manubar. Many studies and considerations within Kutai Timur's forest, mainly of the factors of accessibility extent, KPH Bengalon had been recommended as a model (pilot project) of KPH. This research aims to study some aspects supporting the achievement of the Production Forest Authority Unit's development. A case study was conducted on KPHP (Kesatuan Pengelolaan Hutan Produksi or Production Forest Management Unit) Bengalon in Kutai Timur Regency. This research was conducted in an area that had been planned to be a KPH in Kutai Timur Regency, that is KPHP Bengalon that includes nine districts, they are Bengalon, Karangan, Kongbeng, Muara Wahau, Rantau Pulung, Batu Ampar, Telen, Muara Bengkal, and Long Mesangat. This research combines documentation-study methodologies from various sources of secondary data and direct collection method of primary information from the field through interview technique; structured interview and unstructured interview (through questioner). Field observation was taken within the research location to obtain validation of secondary data. The result shows that four aspects supported the formulation of independent KPHP Bengalon in the Kutai Timur Regency, including 1. The certainty of area status, 2. Natural Resources Potential, 3. KPHP Financing and 4. Society Participation. All of those aspects are essential factors in the realization of KPHP Bengalon. This research suggests that it is needed to: (1) inventory natural resources in the protection-forest area of KPHP Bengalon, (2) determine potential natural resources that can be commercialized as a financing source for KPHP Bengalon; and (3) maximally involve society participation in the management of KPHP Bengalon.
\end{abstract}

Keywords: Forest Management Unit, Natural resource, Area status

\section{INTRODUCTION}

East Kutai Regency has three KPHs known as; KPH Bengalon, KPH Kelinjau, and KPH Manubar. Based on various studies and considerations, including accessibility and area factors, the agreed-upon will be selected for submission as a Model KPH is the KPH Bengalon.

The KPHP (Kesatuan Pengelolaan Hutan Produksi or Production Forest Management Unit) area in Bengalon is geographically located at $0^{\circ} 19^{\prime} 45^{\prime}$ “- $1^{\circ} 4$ '07" $\mathrm{N}$ and $116^{\circ} 41^{\prime} 44^{\prime \prime}-117^{\circ} 50^{\prime} 35^{\prime \prime} \mathrm{E}$, stretching for $97 \mathrm{~km}$ from East to West and $177 \mathrm{~km}$ from North to South, located in the middle of East Kutai Regency with an area of $\pm 664,975$ ha, consisting of production forest covering $\pm 368,003$ ha, limited production forest covering $\pm 256,371$ ha and protected forest area \pm 40,446 ha [1].

Various stages have been carried out by the Forestry Service to realize KPH development in East Kutai Regency, hoping that the KPH development plan can be appropriately recognized. Although at the provincial level KPH formation in East Kutai District has been approved, the KPH development plan has not yet been fully realized at the district level itself. This study aims to study the development and aspects that support the 
achievement of independent KPHP Bengalon in East Kutai Regency.

\section{RESEARCH METHODOLOGY}

\subsection{Location and Time of Research}

This research was carried out at the prospective $\mathrm{KPH}$ formation sites in East Kutai Regency, namely KPHP Bengalon, which included Karangan District, Kongbeng, Bengalon, MuaraWahau, Rantau Pulung, Batu Ampar, Telen, Muara Bengkal, and Long Mesangat District.

This research was conducted during AprilSeptember 2015 in prospective KPH formation sites in East Kutai Regency, namely KPHP Bengalon which included nine districts, i.e, Karangan District, Kongbeng District, Bengalon District, Muara Wahau District, Rantau Pulung District, Batu Ampar District, Telen District, Muara Bengkal District, and Long Mesangat District.

\subsection{Research Materials and Tools}

The materials and equipment used in this study are as follows: (1) regional location map, (2) list of questions for informants (key informants and community leaders, customary heads, and village heads), (3) stationery was used to record observations and results of consultations, and (4) computers and their accessories were used for data processing and report preparation.

\subsection{Objects of Research}

The objects in this study consist of: (1) regulations and policies of the Central Government/Ministry of Forestry and regional policies concerning the development and management of KPH, (2) documents of the KPHP Bengalondevelopment program, and (3) communities living in/around the area, the officials of the relevant agencies

\subsection{Data Retrieval Techniques}

This study combines the documentation study method of various secondary data sources and direct approach, namely primary data collection in the field with interview techniques, structured and unstructured interviews (through questionnaires), and field observations (field observation) at the research location intention of secondary data validation.

\subsection{Data Analysis}

The data that has been collected is then analyzed as follows:

a. Analysis of the situation of KPHP Bengalon development in East Kutai Regency. Situation analysis is used to analyze, understand, manage, and respond to problems in the development ofKHPHBengalon in East Kutai Regency. To analyze the situation, the content analysis method is used. The calculation analysis method was used to analyze the situation.

b. Analysis of aspects that support independent KPHP. An independent KPH can finance its operational activities economically, socially, and ecologically feasible [2]. Some indications of an independent $\mathrm{KPH}$ include the ability of $\mathrm{KPH}$ to absorb labor, invest, produce forestry goods and services in an efficient and effective forest management system [3].

Referring to the various definitions of independent KPHs, the researchers conclude that independent KPHs are KPHs with indicators: (1) certainty in the area's status, (2) availability of natural resources, (3) adequate aspects of KPH financing, and (4) community participation. To formulate and understand the four independent KPHP indicators, descriptive analysis methods and content analyzes are used.

\section{RESULTS AND DISCUSSION}

\subsection{Development Chronology of KPHP Bengalon}

In February 2011, the Director-General of Forestry Planning of the Ministry of Forestry through letter No. S.208/VII-WP3H/2011 conveyed the direction of the reserve for East Kalimantan KPH consisting of $36 \mathrm{KPH}$ units (5 protected forest management units and 31 production forest management units), as many as five cross-district KPH units (1 protected forest management units and four production forest management units), and $22 \mathrm{KPH}$ units in the district (3 protected forest management units and 22 production forest management units).

Based on technical considerations from Regencies/Cities in East Kalimantan and observing the reserve direction, the province of East Kalimantan, through Governor's letter No. 521/7482/Ek/2011, submitted a proposal for the establishment of a KPH consisting of $34 \mathrm{KPH}$ units (five protected forest management units and 31 production forest management units). Currently, the province of East Kalimantan is awaiting the establishment of KPH areas from the Ministry of Forestry. 
Based on the 2010-2015 East Kutai District Forestry Service Strategic Plan, concerning the KPH formation plan, a "road map" of the KPH formation in East Kutai Regency is illustrated as follows:

1. 2012, facilitation of KPH Development, including education and training of KPH Apparatus, visiting KPHs that are considered successful in Indonesia for the learning process, as well as workshop activities to assess the benefits derived from the formation of KPHs in East Kutai

2. 2013, preparation of a book on the management plan for the East Kutai KPH, including three KPH units in the district, namely KPHP Review, KPHP Bengalon, and Manubar KPHP

3. 2014, preparation of KPH Regulations for East Kutai Regency, including Draft Regional Regulations concerning KPH Institutions and derivative rules such as tasks, functions, and authorities granted to $\mathrm{KPH}$.

4. 2015, the establishment of KPHs, the Forestry Service targeted at least one KPH in East Kutai District.

\subsection{Analysis of Independent Aspect of KPHP Bengalon}

\subsubsection{Aspects of Certainty on Regional Status}

The certainty of the status of the area in the KPH development to go to a professional KPHP Bengalon is an essential prerequisite that must be fulfilled for KPHP Bengalon managers, with the certainty of the area, it will guarantee the implementation of KPH management activities from various problems/threats related to the status of the area.

Based on the Forestry Minister's Regulation Number: P.6/Menhut-II/2009 [4] concerning the Formation of Forest Management Unit Areas, at article (5) paragraph (2) point (a), it is stated that one of the criteria for the establishment of $\mathrm{KPH}$ areas is the certainty of the management area. In article (6) paragraph (1), it is stated that the indicator of the certainty of the management area as stated in article (5) paragraph (2) point (a) consists of: (1) located in a permanent forest area after the appointment of boundary stage, or the establishment of a forest area, (2) has a clear and relatively permanent location, area and boundary, (3) each area of the utilization and use of forest area must register its area within the KPH area, (4) $\mathrm{KPH}$ territorial boundaries as far as possible follow natural boundaries.

Based on the review of the KPHP Bengalon development document, up to now, KPHP Bengalon has an area of 707,899 ha consisting of Protection Forest covering 75,219 ha, Production Forest 373,977 ha, and
Limited Production Forest covering an area of 258,703 ha. The report also explained several main problems in the KPHP Bengalon: (1) the boundary management committee has not been formed, (2) the percentage/area of the area has not been determined, (3) changes in regional functions due to changes in the Spatial Plan, (4) control of third parties in forest areas, (5) differences in perceptions between central and regional governments.

When referring to the Forestry Minister's Regulation Number: P.6/Menhut-II/2009 [4] concerning the Establishment of Forest Management Unit Areas, then several essential things that KPHP Bengalon managers must carry out are: (1) immediately form a regional boundary committee, (2) make a clear percentage of the area boundary area, (3) identifying changes in the function of the sanitation according to the spatial plan, (4) identification of regional ownership by third parties and solutions to the conflict and; (5) dissemination between local and central government to equalize management perceptions.

By carrying out several completion stages related to the area's status as described earlier, it is expected that KPHP Bengalon management towards independent KPHP can be achieved well.

\subsubsection{Aspects of Natural Resource Potential}

KPHP Bengalon Forest Area has a high diversity of flora and fauna species. According to information on the potential area of the Kutim Forestry Service, including some business license for utilization of timber forest products that have working areas in KPHP Bengalon, there are at least 55 types of plants (in the form of trees, shrubs, lianas, and rattan) and 223 species of animals (in the form of mammals, primates, poultry, and reptiles) in KPHPBengalon forest area. There are groups of plants and animals classified as protected, both according to Indonesian government law and international law (IUCN).

Information on the KPHP Bengalon area states that out of the total area of 707,899 ha KPHP Bengalon, as many as 632,680 ha have been burdened with a business license for utilization of timber forest products permits. The remaining 75,219 ha are Protected Forests, which means the opportunity to go to independent Bengalon KPHP can only be achieved from the use of certain areas in Protection Forest. Based on Minister of Forestry Regulation No. P.47/MENHUT-II/2013 [5] concerning Guidelines for Criteria and Standards for the Utilization of Specific Areas in Protected Forest Management Units and Production Forest Management Units, mandating that KPHs may only manage/utilize certain areas considered to have economic potential and have not been permitted. In terms of area management, the Minister of Forestry Regulation stipulates in article 6 paragraph 1 that the implementation of forest utilization 
in certain areas of protected forest areas can be in the form of (1) utilization of the area, (2) utilization of environmental services, and (2) collection of non-timber forest products.

Based on the explanation in the Forestry Minister's Regulation No. P.47/ MENHUT-II / 2013 [5] Based on the area of protected forest area with an area of 75,219 ha, this could be an opportunity forKPHPBengalon managers in the utilization of the area as a source of funding for the independent KPHP Bengalon.

From the review of the KPHP Bengalon development plan document, the writer can conclude that the natural resource potential that is owned is still comprehensive whether it is the area that has been burdened by business license for utilization of timber forest products or protected areas, this means that specifically the identification of natural resource potential in protected areas has not been identified. For this reason, it is necessary to take steps from the KPHP Bengalon management to determine the potential of natural resources in protected areas immediately. It is hoped that with the availability of information on the potential of natural resources possessed in protected areas, the management can directly map and commercialize the existing potential.

\subsubsection{KPHP Financing Aspects}

$\mathrm{KPH}$ funding is the most critical factor for the realization of an independent KPH. It has been mentioned in the Forestry Minister's Regulation Number: P.41/Menhut-II/2011 [6] concerning Standards for Facilities and Infrastructure of Protected Forest Management Units and Model Production Forest Management Units explained that in article (2) paragraph (1), it is stated that the government gives facilitation of protected forest management unit Model facilities and infrastructure and production forest management unit Model to encourage the operation of a protected forest management unit and production forest management unit in the field, then paragraph (2) states that the facilitation of facilities and infrastructure of protected forest management unit Model and production forest management unit Model other than by the government as referred to in paragraph (1) can be provided by the Regional Government.

Based on the explanation of the Forestry Minister's Regulation Number: P.41/Menhut-II/2011 [6], it can be concluded that government financing of a protected forest management unit and production forest management unit is limited to facilitation of facilities and infrastructures, while for other activities a KPH must be able to find its funding sources. This issue is a challenge for KPH managers to obtain additional funding sources so that the KPH can run well.
Regarding the use of certain areas in the Protected Forest area, there are current problems faced by KPHP Bengalon management, such as the unavailability of specific data and information about the potential of natural resources in protected forest areas, the current data only shows the potential of KPHP natural resources Bengalon in general. The next problem is that accessibility is very difficult to go to the Protected Forest area is a separate problem for KPHP Bengalon. This has the effect of making it difficult to map out the potentials that the management can develop to reach the independent KPHP Bengalon.

In general, the author tries to recommend several business opportunities to use in certain areas in the KPHPBengalon based on data obtained from the proposed plans and reports on the development of KPHP Bengalon. To be an independent KPHP Bengalon, KPHP Bengalon managers can hold a third party in terms of regional investment as mandated in Forestry Minister's Regulation No. P.47/MENHUTII/2013 [5] article 5 paragraph 2 stating that third-party criteria are: (a) local community, (b) State-owned enterprises, Regional owned enterprises, Privately owned business entities, Cooperatives, Micro, Small, and Medium Enterprises.

\subsubsection{Aspects of Community Participation}

It cannot be denied that there is often conflict between communities around the forest with forest area managers, both in terms of land ownership and utilization of the area. This is certainly an important issue that needs to be considered by the government, especially for the managers of a KPH. This can be addressed through a sectoral paradigm shift to become integrated. Inter-sectoral coordination and cooperation must be based on community empowerment so that community participation as partners in socio-economic development becomes important and begins with local communities' empowerment [7].

Following the Vision of KPHP Bengalon East Kutai Regency are: "Prosperous Communities Towards Sustainable Forests", then the management concept that involves community participation as implemented in Wehea Protection Forest management can certainly be a reference for Bengalon KPHP management in involving participation community in the management.

Law No. 41 of 1999 concerning Forestry [8], in article 70 , point (a) mentioned that Society participates in the development in the forestry sector. In-Law No. 5 of 1990, Article 37 paragraph 3 also states that developing the participation of the government's people, it fosters and enhances the awareness of the conservation of biological resources and their ecosystems among the people through education and counseling [9]. Based on the review of the proposal's 
contents for the Bengalon KPHP management plan proposal and the results of field research, it was found that efforts to involve community participation, including in providing education and counseling, had not been carried out. Based on interviews in the field, it was also pointed out that most of the community did not know what was meant by KPH. This shows that the government's efforts, in this case, the management of KPHP Bengalon to involve community participation in management, were not yet following what was mandated in Law No. 41 Regarding Forestry article 70 and Law No. 5 of 1990 article 37.

\section{CONCLUSION}

With the existence of various problems possessed by KPHP Bengalon both from regional certainty, aspects of natural resource potential, aspects of KPHP financing, and aspects of community participation, it was concluded that the expectation of KPHP Bengalon to become an independent KPHP could not be evaluated.

\section{SUGGESTIONS}

This research suggests that:

1. It is necessary to invalidate natural resources in the KPHP Bengalon protected forest area.

2. The need to determine the potential resources that will be commercialized as KPHP Bengalon funding sources.

3. The need to involve maximum community participation in the management of KPHP Bengalon

\section{ACKNOWLEDGMENTS}

The author expresses many thanks to many who have helped a lot in this research, providing input, guidance, support, and prayer. Undying gratitude to both my parents and family, Main Promoter Prof. Dr. Ir. H. MustofaAgungSardjono, Promoter by Prof. Dr. Ir. Sigit HardwinartoM.Agr, and Prof. Dr. Ir. Juremi, M.Sc. Thank you also to the Testing Team I Prof. Dr. Ir. H. SoeyitnoSoedirman, M.Agr, Prior II Examiner. Dr. Ir. H. AfifRuchaemi, M.Agr., and III Examiner Dr. Ir. FadjarPambudi, M.Sc. Not also forgetting the author's gratitude to the Chancellor of Mulawarman University, Dean of the Faculty of Forestry, and Chair of the Mulawarman University S3 Science Forestry Study Program. Friends of the Doctor of Forestry who cannot be mentioned one by one. Acknowledgments are also conveyed to my friend Kaharuddin, S.Kel., M.Si., who have helped the author.

\section{REFERENCES}

[1] Suriansyah, Plans for Management of the Management Unit for Bengalon KPHP Production Forest in East Kutai Regency, Presented at the Policy Seminar and Institution of Kutim KPH, Samarinda, 2009.

[2] N. Sulistiyono, Human Resource Needs (HR) Towards KPH Independence (Medan: Ministry of Forestry, Faculty of Agriculture, Sumatra Utara University, 2008.

[3] Mugiono, Supporting Mandiri KPH, Forestry R \& D Encourages All Activities Towards KPH. Forda, Bogor, 2014.

[4] Forestry Minister's Regulation No. 6 of 2009 Concerning the Establishment of Forest Management Unit Areas.

[5] Forestry Minister's Regulation No. P.47/MENHUT-II/2013 Concerning Guidelines for Criteria and Standards for the Utilization of Specific Areas in Protection Forest Management Units and Production Forest Management Units.

[6] Forestry Minister's Regulation No. 41 of 2011 Concerning Standard for Facilitation of Facilities and Infrastructure of Protected Forest Management Units and Model Production Forest Management Units.

[7] A. Adimihardja, H. Hikmat, Participatory Research Appraisal, Humaniora Utama Press, Bandung, 2004, pp. 13-14.

[8] Constitution No. 41 of 1999 Concerning Forestry

[9] Constitution No. 5 of 1990 Concerning Conservation of Biological Resources and their Ecosystems.

[10] Forestry Minister's Regulation No. 42 of 2011 Concerning the Competency Standards of the Forestry Technical Field on Protection Forest Management Units and Production Forest Management Units. 